\title{
Åpen framtid - muligheter for bibliotekene
}

\author{
Hilde Terese Drivenes Johannessen
}

Universitetet i Agder

Contact: hilde.johannessen@uia.no

\section{Editorial}

Virak er en konferanse som ligger mitt hjerte nært. Det var den første konferansen jeg reiste på som nyslått bibliotekar i 2008 da konferansen ble arrangert i Oslo og fortsatt het Fagreferentkonferansen. Det var her bibliotekfeltet virkelig åpnet seg for meg da jeg fikk se presentasjoner av bibliotekforskning og ble introdusert for kolleger med samme problemstillinger og utfordringer som jeg nettopp hadde begynt å undre meg over. Jeg følte at jeg var del av et større fellesskap og at dette fellesskapet var på vei mot en viktig faglig utvikling. I 2012 fikk jeg for første gang bli med å arrangere konferansen da den ble lagt til Universitetet i Agder i Kristiansand. Dette var også min første presentasjon på konferanse noen gang hvor jeg la frem eget arbeid med forskningsstøtte sterkt inspirert av arbeidet som munnet ut i PhD On Track. Konferansen førte til at jeg kom i snakk med disse akademiske bibliotekheltene som faktisk kom for å høre på mitt foredrag. Dette var en viktig og motiverende hendelse for meg som inspirerte meg til videre arbeid og etter hvert også publisering av egen forskning. Da konferansen skulle arrangeres i Oslo i 2017, satt jeg i programkomiteen og i planleggingskomiteen da konferansen skulle arrangeres i Stavanger i 2019. Dette ble første gangen på 10 år at jeg ikke kunne delta på selve konferansen fordi jeg byttet jobb. Det var med tungt hjerte at jeg måtte innse at jeg ikke fikk høre Beall snakke om røvertidsskrift, eller treffe gode bibliotekkolleger og diskutere faglige problemstillinger.

Virak-konferansen har for meg vært en av de viktigste nettverksareaene og stedet hvor jeg traff inspirerende kolleger jeg kunne ha engasjerte samtaler i kaffepausen eller over en øl på puben ved dagens slutt. Det er en stor glede å kunne bidra som gjesteredaktør i et av Norges få fagtidsskrifter for bibliotekfag. Bibliotekforskningen i Norge er i vekst og jeg skulle ønske enda flere av de inspirerende foredragene og viktige utviklingsarbeidene hadde blitt publisert $\mathrm{i}$ form av forskningsartikler eller beste praksis artikler. Det skjer mye i norske fagbibliotek og vi trenger å dele dette og inspirere hverandre.

Temaet for dette spesialnummeret er det samme som fjorårets Virak-konferanse «åpen framtid - muligheter for bibliotekene». Felles for mange av bidragene er at det fokuseres på 
posisjonering av bibliotekene for framtiden og hvordan dette kan løses via samarbeid og kommunikasjon med fagmiljøene på deres respektive institusjoner. Bidragene i dette spesialnummeret presenterer en rekke muligheter som har blitt omfavnet og gjennomført av bibliotekene. Nummeret inneholder to forskningsartikler, fem beste praksis artikler og en rekke abstracts fra presentasjoner på konferansen i Stavanger.

Eksempler på hvordan samarbeid mellom bibliotek og fagmiljø kan fungere for å bedre studenters akademiske skriveferdigheter finner vi i Almlies forskningsartikkel «Akademisk fagskriving på ingeniørstudiet», hvor hun presenterer funn fra en undersøkelse gjort blant ingeniørstudenter som har deltatt på kurs i akademisk skriving. Hun fokuserer på at samarbeid mellom vitenskapelig ansatte, biblioteket og skrivelærer er en fruktbar tilnærming.

Siv Olsen og Eva Sauvage har gitt et nyttig bidrag til open access-debatten med spesielt fokus på rørvertidsskrifter. De viser at forskere generelt er negative til open access og at det er et stort behov for «hvite lister» over godkjente publiseringskanaler.

I beste praksis artiklene deles nyttige erfaringer fra utviklingsprosjekter og innovasjon i norske fagbibliotek som kan inspirere til etterfølgelse. Et eksempel Erik Myking Lieunghs artikkel «Skal vi virkelig lage en podcast?» hvor han presenterer Universitetsbiblioteket ved UiT - Norges Arktiske Universitets arbeid med sin egen podcast. Fokuset her er på hvilke problemstillinger, og ikke minst muligheter som kan oppstå i denne sammenheng.

Karin Rydving presenterer i sin artikkel «Om forskningsstödjande tjänster för forskningsdata i UH-bibliotek» hvordan norske fag- og forskningsbibliotek legger til rette for støtte for forskningsdata. Rydving konkluderer med at det er mye som skjer på dette området, men at det fortsatt er rom for forbedring og utvikling. Hun sier videre at dette kan bli en viktig arena for hvordan bibliotekarrollen videreutvikles. Det som er avgjørende her er forskerens rolle og hvordan vi som bibliotekarer kommuniserer og samarbeider med fagmiljøene for å forstå deres forventninger og behov.

Solhaug og Rom Jensen beskriver i sin artikkel «Systematic searches: a new area of cooperation between the library and the social sciences» hvordan det jobbes med systematiske søk i samfunnsvitenskap ved NTNU Universitetsbiblioteket. Også her fokuseres det på kommunikasjon og samarbeid som et viktig virkemiddel for utvikling og gode resultater.

Solhaug og Lillevoll Loranges bidrag om Skrivenatt ved NTNU Universitetsbiblioteket beskriver UBs tilbud om skriveopplæring og veiledning som en viktig samarbeidsarena med fagmiljøene hvor bibliotekets bidrag er kunnskap innen vitenskapelig litteratur, vitenskapelig publisering og referanseskriving, og ikke minst som knutepunkt og arbeidsplass for studentene.

Burke fokuserer i sin artikkel «Remarks on the writing centre and the future library» på hvordan skrivesenteret på UB Oslo er en viktig ressurs i studenters skrivearbeid og også han trekker frem at dette er avhengig av samarbeid med fagmiljøene. 
Bibliotekarer i norske fag- og forskningsbibliotek ble bedt om å komme med innspill om hva bibliotekenes muligheter ville bli i den åpne fremtiden. De har levert mange interessante bidrag som ser ut til å enes om at mulighetene for posisjonering ligger i samarbeid og kommunikasjon med deres respektive institusjoners fagmiljøer. Jeg ser frem til å reise til Trondheim i 2022 når instituttledertilværelsen er over og jeg returnerer til bibliotekfaget. Framtiden er åpen og full av muligheter for bibliotekene!

Universitetsbibliotekarer ved UB Agder Ingrid Galtung og Erik Adalberon har vært redaksjonsmedlemmer av dette spesialnummeret. Deres gjennomlesinger og gode diskusjoner har vært viktig for det ferdige arbeidet. De er begge reflekterte og dyktige forskningsbibliotekarer som bidrag til utvikling av bibliotekfeltet generelt og til dette spesialnummeret spesielt. Takk! 